Copyright (C) 2015 by Academic Publishing House Researcher

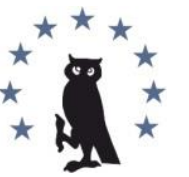

Published in the Russian Federation

European Researcher

Has been issued since 2010.

ISSN 2219-8229

E-ISSN 2224-0136

Vol. 101, Is. 12, pp. 775-782, 2015

DOI: 10.13187/er.2015.101.775

www.erjournal.ru

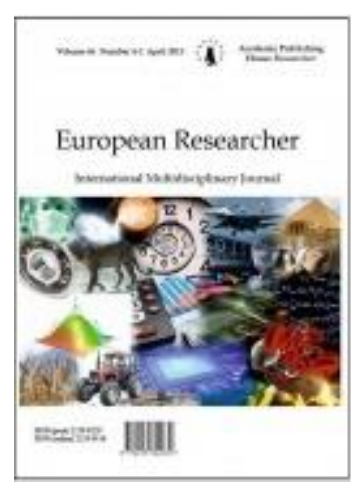

Pedagogical sciences

Педагогические науки

UDC 37

\title{
The Mass and Individual Terror in the Mirror of the Soviet and Russian Cinema (the Feature Films of the Sound Period) and Media Literacy Education
}

\author{
Alexander Fedorov
}

\author{
Anton Chekhov Taganrog Institute, Russian Federation \\ branch of Rostov State University of Economics \\ Prof. Dr. (Pedagogy) \\ E-mail: mediashkola@rambler.ru
}

\begin{abstract}
This article gives the way for hermeneutic analysis of the topic of the mass and individual terror in the mirror of the Soviet and Russian cinema (the feature films of the sound period). The hermeneutical analysis suggests media text comprehension through comparison with historical, cultural tradition and reality; penetration of its logic; through comparison of media images in historical and cultural context by combining historical, hermeneutical analysis of the structural, plot, ethical, ideological, iconographic / visual, media stereotypes and analysis of media text characters. An analysis of this kind of media texts, in our opinion, is particularly important for media literacy education of future historians, culture and art historians, sociologists, psychologists and educators.

Keywords: terror, Russian cinema, films, hermeneutical analysis, Soviet, USSR, film studies, media texts, media literacy, media education, information literacy.

\section{Introduction}

Proceeding from the research that was devoted to different aspects of the Theory and History of Cinema-Art, as one of the branches of the Theory and History of Art, we can make a conclusion: the analysis of the theme of terror and terrorism in the Russian cinema remains uncharted; no existing school book, monographs or thesis contain a chapter devoted to this vital question. This article gives the way for hermeneutic analysis of the topic of the mass and individual terror in the mirror of the Russian cinema (the feature films of the sound period). The hermeneutical analysis suggests media text comprehension through comparison with historical, cultural tradition and reality; penetration of its logic; through comparison of media images in historical and cultural context by combining historical, hermeneutical analysis of the structural, plot, ethical, ideological, iconographic / visual, media stereotypes and analysis of media text characters. An analysis of this kind of media texts, in our opinion, is particularly important for media literacy education of future
\end{abstract}


historians, culture and art historians, sociologists, psychologists and educators. An analysis of this kind of media texts, in our opinion, is particularly important for media literacy education of future historians, culture and art historians, sociologists, linguists, psychologists and educators.

\section{Materials and methods}

The main materials for this article was the area: the books, articles and films about the theme of terror and terrorism in the Soviet and Russian cinema. I used also the method of hermeneutic analysis of the cultural context of media texts (Eco, 1976; Silverblatt, 2001). This method connected with the key concepts of media literacy education (media agencies, media categories, media language, media technologies, media representations, media audiences etc.).

I have these objectives:

- to define the place and role of the theme of mass \& individual terror in the Russian cinema art of the sound period;

- to study a social, cultural, political and ideological context, main stages of the evolution of the theme of the course in Soviet and Russian cinema, directions, aims, tasks of the development of this theme, basic authors' concepts of Soviet and Russian feature films of the 1930's-1990's, where to some extent the theme of mass \& individual terror is touched upon;

- the analysis and the classification of the model of contents, genre modifications, stylistic aspects of the Russian cinema art of sound period, dealing with the terror theme (the classics in the history of Russian cinema - the works of Friedrich Ermler, Mikhail Romm, Leo Arnshtam, etc. and films that haven't been analyzed yet - made in the 1980s-1990s as well).

\section{Discussion}

At present the Theory and History of Art, Cinema art lacks researches, monographs, devoted to the theme of mass \& individual terror in Russian cinema of the sound period (1930s-'90s). The researches of Russian specialists in the Theory and History of Arts were until now devoted to such traditional themes as 'historically-revolutional', 'heroic-patriotic', war, etc. In this theme context films of 1930s-1940s were viewed, in this or that degree concerning our topic, for example, works by I. Dolinsky, S. Ginsbourg, N. Lebedev, A. Groshev, V. Zhdan, N. Tumanova, L. Belova, etc. The theme of terror as a separate theme was not regarded in the published works analyzing films of the 1950s-1990s either (N. Zorkaja, L. Annensky, Y. Bogomolov, V. Demin, I. Waisfeld, G. Kapralov, M. Turovskaja, K. Raslogov, etc.). Therefore, no Russian research claimed to have a special analysis of the theme of mass and individual terror in the Russian cinema art.

Thus, the problem of the course is, for the first time in the Theory \& History of Art, to study, analyze and make it a system of evolution of the interpretations of the themes of terror and terrorism in Russian cinema-art of the XXth century, taking into consideration the social \& cultural, political \& ideological context, types of plot schemes and characters, basic authors' concepts of the themes of mass \& individual terror, peculiarities of the artistic style. The chronological framework: the sound period of the Russian cinema-art /since 1931/ till the present day.

The general social \& cultural context, within the limits of which the problem is, is the following: Mass and individual terror is one of the most dreadful crimes of the XXth century. During its biggest part of existence, the Russian cinema-art touched upon the theme of terrorism. In different years the interpretations of the terrorists' action were not only different, but quite opposite too. For instance, in the early 1930s-1970s the activity of Russian Communists Special police (V.C.K.) was interpreted positively, in the end of 1980 s \& 1990 S V.C.K. was shown as the organization that headed the mass terror. In the films made in the '6os (Sofia Perovskaya by Leo Arnshtam, etc.) about individual revolutionary terror, the main characters were treated sympathetically, while in the films of the 1990 s (screen versions of the novels by Boris Savinkov, etc.) individual terror is unequivocally turned down.

No doubt, the terrorism theme was never a leading one in Russian cinema art, despite the fact that for some political, economic, and military reasons in the Russian society of the '9os, terrorism began to increase threateningly. Cinema in different genres (drama, thriller, detective story or a comedy and parody) began to turn to the problem of this course more and more often. 


\section{Results}

1. The mass and individual terror in the mirror of the Soviet and Russian cinema: the Stage of the 1930 .

The aims: to define the place and role of the theme of mass \& individual terror in the Russian cinema art of 1930s; to study the social, cultural, political, ideological context, directions, aims and tasks of the development of this theme, model of contents of films on the topic, their genre modifications, authors viewpoints and stylistics.

The 1930 s are one of the most complicated, contradictory and contrasting periods in the history of the Russian film industry (Turovskaya, 1989). Directors - socialist realists had to bless and sometimes glorify mass repression of 'public enemies', in a word aid adoption of the ideological myths of Stalinism into mass consciousness (Turovskaya, 1989; Urenev, 1997). The totalitarian system realized the political \& ideological importance of the theme of terror. Though it didn't occupy the leading place in the Russian cinema, its propaganda role was rather big. With the help of a screen, the necessity of the 'revolutionary terror' towards 'class enemies', 'alien elements', etc. was put into the heads of millions of Russians. Such films became the apparent basis for the adoption of Stalin's thesis saying that as socialism develops, the class struggle should grow and become violent...

General social, cultural, political \& ideological context of the 1930s:

- mass terror in the totalitarian regime towards peasants that lead to the hunger in early 1930s;

- total abolition of the private property (that was revitalized during the Russian communist's New Economic Policy of the 1920s;

- intensive industrialization (mainly of heavy and military industries) at the cost of enormous efforts of people);

- mass repression of millions of Russians - from the lowest to the highest strata of society; ideology;

- intensive adoption of communism with the intensive repression of the Christian

- intensive militarization of the country, unleashing war conflicts.

The film industry that touched upon the terror theme to support the main lines of the state policy of the Stalin's regime, was set strict propaganda tasks which served as the basis for the film authors' conceptions:

- to prove that Bolsheviks' enemies camouflage themselves and are ready to make an act of terrorism any minute to seize power;

- $\quad$ to show that terror towards the public enemies is justified and inevitable;

- to convince viewers that anyone of their family, relatives, neighbors and friends can turn out to be a 'class enemy', who must be revealed and destroyed.

Genre modifications: on the whole the genre is that of a drama (war epic, historical). The style of such films was determined by the strict rules of so-called 'socialistic realism': instead of the experimental (especially in the form) film production of the '20s, the style of the ordinary, everyday life (in fact, often embellished) emerged with its consistent plot, theatrical performance of actors...

The dominating models of film plots: terror of Bolsheviks towards the so-called 'class enemies' and 'public enemies' and vice versa (The Great Citizen by F. Ermler, Aerograd' by A. Dovzhenko, The Party Card by I. Pyriev, Lenin in 1918 by M. Romm, etc.). The latter film by Romm had a mission to justify mass repression (Urenev, 1997). As far as films about collectivization are concerned, in such films a dramatic stereotype exists: 'poor peasants at once realize the advantages of a collective farm, middle class peasants hesitate, 'kulaks' (rich farmers) undertake sabotage and murders with the help of White Guard officers, foreign spies, priests and salesmen coming from the blue (Urenev, 1997).

Even children's films of Stalin's period were swarming with enemies. In the 1930s, when Stalin destroyed peasantry, enemies were usually 'kulaks', White Guards, who helped spies \& saboteurs. The great support for enemies of the Soviet regime was clergy because at that time thousands of Russian new martyrs were killed by the godless power.

2. The mass and individual terror in the mirror of the Soviet and Russian cinema: the Stage of the 1940 . 
The aims: to define the place and role of the theme of mass \& individual terror in the Russian cinema art of 1940's; to study the social, cultural, political, ideological context, directions, aims and tasks of the development of this theme, model of contents of films on the topic, their genre modifications, authors viewpoints, stylistics, the differences from the stage of 1930's.

At the beginning of the war with the Nazis, Germany has visibly changed the social, cultural \& ideological context, against which the Russian film industry developed. Class struggle and the struggle with religion stepped back, there was no mass repression against farmers, the leading place was taken by the struggle with fascists (the Germany with which Stalin had previously set friendly relationships).

General social, cultural, political \& ideological context of 1940s:

- hostilities on the territory of Russia from 1941 to 1944 and the war in the Eastern Europe \& in the Far East in 1944-1945;

- mass terror of Nazis towards the Russians on the occupied territories (concentration camps, mass shootings, etc.);

- intense development of war industry, re-equipment of many plants to serve military purposes at the cost of peoples' efforts;

- $\quad$ adoption of the communism ideology to patriotic slogans;

- establishment of totalitarian regimes, that were totally dependent on the Kremlin almost in all the countries of the Eastern Europe in the late 1940s;

- intense reconstruction of the Russian post-war economics in the late '40s;

- come-back of mass repression in the late 1940s - early 1950s (struggle with cosmopolitanism, anti-Semitic campaign, etc.);

The film industry, dealing with the terror theme to support the main policy of the Stalin's regime of the 1940s, was set the following propaganda tasks, which made up the basis for the artistic conceptions of film authors:

- to show that the Nazis terrorize Russian people and want to make them slaves;

- to convince the audience that return terror is justified \& necessary to win the war;

- $\quad$ to convince the audience that one should be on alert, because Nazi agents \& saboteurs who may be nearby; must be disclosed \& destroyed;

Genre modifications: generally a drama (war, historical). The style of these films is not much different from those of the previous decade, however there's more realism in showing war in everyday life. The dominating models of film plots: terror of the Nazis towards the Russians (shootings, executions, tortures, etc.), return terror of the Russians (partisan raids, spies, shootings of the Nazis, etc.) towards the Germans (Rainbow by M. Donskoy, Zoya by L. Arnshtam, The Young Guard by S. Gerasimov, etc.).

The playwright stereotype: Nazis destroy the peaceful, unruffled, happy life of people and capturing a town or a village they begin mass terror towards the population, including women and children, drive Russians away to Germany for hard labor, etc. People begin to struggle with enemies: in the army, in partisan groups, in secret organizations. In passing spies \& saboteurs, traitors are disclosed... The only exception was the film by Sergei Eisenstein 'Ivan the Terrible' in which the merciless and bloody repressive state mechanism was shown, 'Oprichnina' (Special tsar's police) terrorizing Russia by the tzar's will. (Ivan the Terrible who turned into a dictator at the cost of thousands of lives of his subjects.) All this was in fact an allegorical representation of Russian reality of the 1930s-1940s. No wonder that the second part of the film, were Eisenstein's protest against terror \& totalitarian power was evident, was prohibited by Stalin's regime...

3. The mass and individual terror in the mirror of the Soviet and Russian cinema: the Stage of the 1950 - Early 1980 s.

The aims: to define the place and role of the theme of mass \& individual terror in the Russian cinema art of 1950 s - early 1980s; to study the social, cultural, political, ideological context, directions, aims and tasks of the development of this theme, model of contents of films on the topic, their genre modifications, authors viewpoints, stylistics. The differences from the stage of 1930 and 1940 .

The following stage may be divided into two main periods - Khrushchev's 'thaw' (middle 1950s - middle 1960s) and Brezhnev's 'stagnation' (late 1960s - early 1980s). However with all differences \& peculiarities of these periods, the cinema version of the theme of mass \& individual 
terror was approximately the same: terror as it is was condemned, however the attitude towards the so-called 'revolutionary terror' was rather sympathetic...

General social, cultural, political \& ideological background of the 1950s - early 1980s:

- rejection of the class struggle within the country, declaration of the creation of the united Soviet people, who had no national, ethnic, class or race problems;

- official rejection of the idea of the world revolution \& dictatorship of the proletariat; declaration of the policy of 'peaceful coexistence of socialistic and capitalistic systems', keeping the so-called 'ideological struggle';

- liquidation of mass terror of the state against its own citizens, preserving local struggle with people who had their own opinion (B. Pasternak, A. Saharov, A. Solzhenitsyn and others);

- continuation of the industrialization (mainly of the hard \& military industries). In fact rates of this development slowed down and it took less people's efforts; until the beginning of the ' 8 os, when crisis tendencies in the ineffective plans of the state economics began to show up because of the fall in oil prices;

- continuation of the intense adaptation of the communism ideology (in its new Leninorientated, post-Stalin variant), struggle with Christian ideology is less intense;

- continuation of the intense militarization of the country, unleashing war conflicts (in Africa and Asia), intervention in Hungary (1956) Czechoslovakia (1968); supporting militaries, including communist regimes in the 3 rd world countries.

The film industry that touched upon the theme of terror to support the state policy of the authoritarian Soviet regime was set the following propaganda tasks that served as the basis for the conceptions of author's of a film:

- to show that terror during the Civil War was forced and led to people's sufferings;

- to ignore or at least to conceal the true scale of mass terror in the 1930s, concentrating mainly on the theme of war terror in the 1940s;

- $\quad$ to convince the audience that the so-called 'revolutionary terror of Bolsheviks' was made with noble aims, and terrorists themselves were honest, true to their noble ideals, protectors of the rights of oppressed people;

- to condemn terrorists who highjack planes, ships and blow up bombs.

Genre modifications: drama (war, historical), western (seldom 'eastern'), - tragic comedy, melodrama. The style of the majority of such films was no more determined by the laws of socialistic realism. Along with very much traditional screen versions of Quiet Flows the Don, The Road of Sorrows and Optimistic Tragedy some daring adventure films like Elusive Avengers and sometimes quite murderous westerns ("eastern") by Samvel Gasparov appeared on the screen. In the latter films the action took place during the Civil War in Russia and mutual hatred of the fighting sides was shown as the inevitable genre rules of the game. The destruction of dozens of people was shown as some circus performance with fountains of blood.

The appearance of milder models of the interpretations of the terror, which lack the aggressive mercilessness and explicitly of the models of the 1930's-1940's; terror towards the class enemies is still regarded as a positive one. However, often the accent is put on it being forced, temporal and sometimes even mistaken.

The dominating models of the film plots: terror towards the so-called 'enemies' (domestic \& foreign) and terror of enemies against the authorities, its representatives \& peaceful population.

The playwright stereotype of the films on the 'historical-revolutionary' topic: the poor are enthusiastic about the new rule by Bolsheviks, 'middle class' and intellectuals are uncertain; terror, blood and war frighten them. But in the long run they understand, that Bolsheviks took repressive actions unwillingly in the name of the future happy life of working people. Thus, those who had doubts, begin to understand the rightness of the theory of revolutionary terror and dictatorship of proletariat (The Road of Sorrows, etc.).

Special gratitude is given by the authors of films to Special Commission VCK (Special Police Service); men who, with 'clean hands', with fire and sword burn the 'enemy infections' (that is, millions of people) out of the Russian land (The Operation 'Trust', Peters, Born by the Revolution, The Failure, The Failure of the Operation 'Terror', December, 2O, etc.). An attempt by Alexander Askoldov in his drama Commissar' to disclose the true tragedy of the Civil War and antihuman nature of terror was mercilessly suppressed: the film was banned for 20 years. The same happened to Alexei German (by the way, only hinted, coded) attempt to show in his film My Friend Ivan 
Lapshin the work of the Special Policemen in the 1930s. Among the films that showed terror in its most dramatic \& true nature was Run (based on the novel by Mikhail Bulgakov) and The Slave of Love...

The playwright stereotype of WWII films stayed nearly the same that in the 1940s but more true-to-life. For example, in the film Spiritually Strong, methods of the individual terror which were used against the Nazis during the WWII by the Russian secret agent Kuznetsov, were absolutely justified while his terror acts against the Nazi officers had a reversed effect: for each Nazi officer that was killed by Kuznetsov, fascists shot a hundred of Russians...

In films Sofia Perovskaya and Executed at Dawn, terrorists who attempted to kill the Russian tsar were shown with sympathy. But in the The Sixth of July, the act of terrorism by the left-wing socialist-revolutionists, who killed the German ambassador in 1918 was condemned...

Even more condemned were terrorist activities of the famous leader of socialistsrevolutionists Boris Savinkov in films, as The Failure and Operation 'Trust'... Of course, pure criminal terrorism (The Pirates of the XX Century, The Fight in Snow-Storm) was condemned too. Though in the early 1980 s in the film A Story of a Stranger), perhaps for the first time in the Russian film industry, not only the expediency of revolutionary individual terror, but also the moral qualities of revolutionists themselves were brought in question (it goes without saying that the main character was not a Bolshevik...).

In short, certain changes happened in the attitude towards the theme of the terror in the cinema, even though the clichés of the 1930s-1940s milder models of showing terror reappeared. They lacked the furious mercilessness and flatness of the models of the 1930s-1940s. Terror towards class enemies is still shown positively. However, the accent is on its forced, temporary and sometimes erroneous nature.

4. The mass and individual terror in the mirror of the Soviet and Russian cinema: the Stage of the late 1980s - 1990s and begin of 2000 s.

The aims: to define the place and role of the theme of mass \& individual terror in the Russian cinema art of the late 1980s -1990s and begin of 2000s; to study the social, cultural, political, ideological context, directions, aims and tasks of the development of this theme, model of contents of films on the topic, their genre modifications, authors viewpoints, stylistics. The differences from the stage of 1930s, 1940s, 1950s-1970s.

This stage can be divided into two main periods - Gorbachev's 'Perestroika' (1985-1991) and Yeltsin's reforms (1992-nowadays). These periods are different from each other in many ways. They are similar, however, in condemning the individual and mass terror, whatever form it takes.

General social, cultural, political and ideological background of the late 1980s -1990s and begin of 2000s:

First Period

- Gorbachev's declaration of 'Perestroika' and 'Glasnost', democracy, freedom of speech and improvement of socialism;

- official blame of mass and individual terror and rehabilitation of millions of innocent people who were convicted and imprisoned or shot;

- rejection of the ideological struggle and withdrawal of the troops from Afghanistan, declaration of the policy of disarmament;

- gradual rejection of the censorship and free exchange of people \& ideas between the USSR and Western countries;

- economic and ideological crisis which led, in the long run, to the attempt of a conservative upheaval in the summer of 1991;

- $\quad$ the decay of the Soviet Union in 1991;

Second Period.

- the beginning of the economic reforms, the revival of the private property, 'shock therapy'; sudden division of the society between the few rich and many poor people;

- an attempt of coup-d'etat in the autumn of 1993;

- the crisis of reforms; the war in Chechnya, an attempt to solve economic problems with the help of money borrowed from the West; decay of the Russian industry;

- At this point, as the censorship was practically abolished, film producers got an opportunity for the first time to turn to the most vital themes that were banned before, such as the theme of mass terror and repression during the communism regime. 
- stabilization of Russian economics in 2000-2007;

- new economic crisis from 2008.

Below is the approximate list of ideas that served as the basis for the authors' conceptions of films on the topic of the mass and individual terror in the mirror of Russian cinema:

- terror during the civil war, as the fratricidal war itself was the tragedy of the Russian people;

- mass terror of the 1920 - early 1950 s was the consequence of an anti-human policy of Lenin and Stalin; start to it.

- terror, whatever form it takes, can not be justified, neither can be the ideology that gave

Genre modifications: drama (war, historical), western, tragic comedy, melodrama, comedy, parable. The styles are also different. Besides traditional realism (The Sign of Misfortune, The Law, Nikolai Vavilov', etc.) some grotesque, ironical films are made (The Feasts of Valtasar, 10 Years without the Right of Correspondence, etc.), and there is an exquisite stylization of the visual manner, as in 'The Late Stalinism' (Moscow Parade). Shocking films, that show mass terror and violence really close, appear (Go and Watch, From Hell to Hell).

Dominating models of a plot:

- mass terror of Nazis during the Second World War and terror of the Communism regime towards its own citizens as well, destroyed human personality, turned people into hangmen and victims of the totalitarian dictatorship (Go and Watch, From Hell to Hell, Advocate Sedov, Enemy of People - Bukharin, etc.). This model showed itself especially visibly in the films about mass deportations of Caucasian people in the 1940s (A Golden Cloud Slept, Coldness, A Road to the Edge of a Life);

- $\quad$ an ordinary man, trying not to be involved in politics becomes a victim of Stalin's terror and is imprisoned in a concentration camp. Only there does he realize the anti-human character of the communist regime (Coma, Lost in Siberia, What a Wonderful Game, etc.), or people who believe in the justice of the communist ideas one day from experience the Stalin terror themselves, but they see it clearly only too late (Tomorrow Was the War, Inner Circle, Burnt by the Sun');

- 'Revolutionary terror' and 'ideological terror' attracts people with the aggressive desire of power in the first place, psychos who this way or the other, want to leave their bloody trace in history (Tsar's Murderer, Trotsky, Romanov - the Tsar's Family, Plumbum, Special Police Officer, Made in the USSR, etc.);

- a common man of the second half of the XXth century goes to serve in the army (or finds himself in the prison or a work camp), where he comes across cruel terror not very different from that of the Nazis or Stalin's (No Limits, The Guard, The Reed Paradise, Do - one!', etc.);

- $\quad$ in the streets of today's Russian cities mobs terrorize people, the authorities can do nothing, a hero alone fights against thugs ( $A$ Day of Love, Wild Beach, etc.);

- terrorists highjack planes, buses, and ships. Courageous and strong heroes disarm them (Crazy Bus, Gangsters in the Ocean, etc.).

Thus, at this stage films where terror is categorically disapproved as antihuman method appear more and more often; films in which mass and individual terror is condemned no matter whose side is using it.

\section{Conclusions}

The topic of the mass and individual terror in the mirror of the Soviet and Russian cinemaart (the feature films of the sound period)' is important for Russian students, for example, - future pedagogues, because Russian society needs the true History of Modern Screen-Arts. During the analysis of the scientific literature and concrete works of Russian cinema art of the 1930s-1990s2000s, touching upon the theme of terrorism, students will know the aims and tasks (political, ideological, moral, aesthetic, etc.), plot, genre models, basic authors concepts of various interpretations of this theme in Russian cinema. And when students finish the university, they will teach pupils the true History of Russian Cinema-Art, including the theme 'Mass and Individual Terror'.

The results will have a practical significance for the Theory and History of cinema-art. The course of the lecture 'The Mass and Individual Terror in the Mirror of the Russian cinema-art (The Feature Films of the Sound Period)' may be used for the study of the History of cinema art by 
scholars in the sphere of Arts and by students of the specials courses in Universities - for the development of the creative personality of a student, his faculties for the perception, interpretation, analysis and the appraisal of the author's position in a film. On this basis, the eagerness of a future teacher for the education of pupils, with the help of the screen arts, is forming.

The aims of the seminar for the students are:

- to see the most typical Soviet and Russian films with the theme of mass or individual terror;

to discuss these films with students in the political and social and cultural context.

- the development of the creative \& critic mentality of students, their faculties for the perception, interpretation, analysis and the appraisal of the author's position in the film. On this basis the eagerness of future teachers for the education of pupils, with the help of the screen arts, is forming.

- the collective discussion of the film(s): the artistic analysis of the film(s) - the consideration of the episodes' contents, with the maximum brightness embodying the typical conformity to natural laws of the film on the whole; the analysis of the logic of author's mentality; the definition of the author's conception and the basis of the personal attitude of students to that or another position of the creators of the film(s).

The typical questions:

What is the culmination's episodes of the film? What is the main film conflict? What is the hero's character? What is the author's conception of this film? What is the author's position about mass or individual terror? What is the difference between the interpretation of theme of mass \& individual terror in the Soviet and Russian cinema of 1930's, 1940's, 1950s-1970s, 1980s, 1990s, etc.

The criteria of studying the cinema-art's development of a student audience:

- the sensory criterion: the frequency of the association with the cinema art, the skill to orientate themselves in their stream - that is to choose favorite genres, themes and so on;

- the understanding criterion: the knowledge of the history of Russian cinema art, concrete works of the cinematograph, including films with the theme of Mass and Individual terror;

- criterion of the motivation: the emotional, hedonistic, compensatory, aesthetic and other motives of the contact with the cinema art;

- the appraisal, interpretative criterion: the level of the perception, the faculty for the audiovisual thinking, the independent critical analysis and synthesis of the space and time form of the narration of the cinema art's work (including, the identification with the hero and author, the understanding and appraisement of the author's conception;

- the creative criterion: the level of the creative basis in the different aspects of the activity, first of all - perceptional, aesthetic, analytical.

Basing on the different classifications of the standards of the aesthetic perception, suggested in the researches, and connected with the problems of the Media education, I came to the following variant, corresponding to the aims and tasks of my program: the standard of the "initial identification": the emotional, psychological coherence with the screen environment and the plot /bond of the events/ of the narration; the standard of the "second identification": the identification with the hero of the work of a cinema art; the standard of the "complex identification": the identification with the author of the work of the cinema art, preserving the "initial" /primary/ and "secondary" identification / with the following interpretation/.

\section{References:}

1. Eco, U. (1976). A Theory of Semiotics. Bloomington: Indiana University Press. Silverblatt, A. (2001). Media Literacy. Westport, Connecticut. London: Praeger.

2. Turovskaja, M., et al. (1989). Cinema of totalitarian epoch. Moscow.

3. Urenev, R. (1997). Soviet cinema art of 1930-s. Moscow: VGIK. 